\title{
Scraps and Sketches: Miscellaneity, Commodity Culture and Comic Prints, 1820-40
}

\section{Brian E. Maidment}

The title of this essay, Scraps and Sketches, is borrowed from a collection of miscellaneous images published by George Cruikshank serially in annual volumes between 1828 and 1832, and much reprinted throughout the subsequent fifty years

see fig. 1). ${ }^{1}$ It was a characteristic publication by a caricaturist of that period - an oblong folio that used the opportunity offered by this distinctive format to assemble a variety of etched images into something approaching a collection. Many pages were built up of small and miscellaneous images, humorous observations rather than fully developed caricatures, derived from the wood engraved vignettes that were beginning to dominate comic visual culture, and laid out on the page in support of a slightly larger central image (see fig. 2). Sometimes small images were grouped into something approaching a thematic order drawing on such stock caricature topics as 'the march of intellect' (see fig. 3). A few pages offered full-plate highly developed images, the most famous being 'London Going Out of Town' see fig. 4). But the staple images remained vignettes built round visual/verbal puns, offering a humorous or satirical gloss on a common phrase or saying as if translating the verbal into graphic terms implied some kind of shift of register with the spoken word subverted by the comic visuality of the caricaturist (see fig. 5). Cruikshank's title, Scraps and Sketches, combined a self-consciously rehearsed modesty with commercial good sense. Despite the immediate implication that the album was nothing more than a kind of graphic fidgeting, the offcuts from the planks of fully developed single plate caricature, Cruikshank nonetheless also alluded to something which was becoming deeply inscribed into graphic culture at exactly this moment the idea of the 'scrap', that is to say images deliberately produced in sheets for cutting out and re-assembling on the pages of albums and scrapbooks. The implication of the term is that these are images requiring little artistic effort in their making, only a little more in their consumption and appropriation into the rituals of

Brian E. Maidment, Scraps and Sketches: Miscellaneity, Commodity Culture and Comic Prints, 1820-40

19: Interdisciplinary Studies in the Long Nineteenth Century, 5 (2007) www.19.bbk.ac.uk 
assembling the scrapbook, and yet of some considerable commercial value in a burgeoning marketplace. This essay is the beginning of an exploration of the idea of the scrap and its place in the social history of visual culture, concentrating on commercial and formal issues rather than the social analysis to be found in scraps.

Although usually described by historians of the graphic arts as a blank moment between the demise of the eighteenth-century caricature tradition and the emergence of the Victorian comic illustrators, ${ }^{2}$ the period between 1828 and 1840 was one of massive commercial dynamism and experimentation in the field of mass-produced visual culture. Even leaving aside the far-reaching implications of the emergence of mass circulation periodicals using wood engraving (such as the Mirror of Literature founded in 1821 or the Penny Magazine in 1832) and the immediate impact of lithography on the mass production of images, the visual culture produced in the 1820s and 1830s in search of new markets among the urban middle classes was startlingly inventive and wide ranging. The decade saw a number of short-lived but vigorously exploited fads especially in the use of the comic in ways beyond the expensive and essentially genteel mode of single plate engraved caricature. The most obvious example of such inventiveness is the comic annual, pocket-sized Christmas volumes which combined humorous verse on the foibles of genteel life with picaresque prose narratives of urban adventures and small scale travels and, more pertinently here, a mass of wood engraved comic illustrations. ${ }^{3}$ The most famous example is Hood's Comic Annual, which ran from 1830 to 1839 with an additional volume in $1842,{ }^{4}$ but there were several others such as the Comic Offering (edited by a woman), The Humourist, Seymour's Comic Album, and most popular of all the New Comic Annual, a publication which seems to have been widely

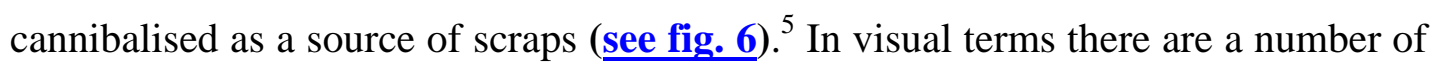
issues to be noted. Basically the illustrations in comic annuals formed a hybrid of a Regency mode of wood engraved caricature illustration - finely drawn, delicately linear and highly naturalistic - and something closer to the woodcut tradition, using

Brian E. Maidment, Scraps and Sketches: Miscellaneity, Commodity Culture and Comic Prints, 1820-40

19: Interdisciplinary Studies in the Long Nineteenth Century, 5 (2007) www.19.bbk.ac.uk 
bold linear simplifications and theatrically simple gestures, postures and expressions. They occurred in the text not so much as illustrations but as freestanding 'jokes', frequently dependent on a visual/verbal pun for their humour. My favourite, an exquisitely subtle one, is this image of 'Kew Bridge' from the 1834 Comic Annual (see fig. 7). ${ }^{6}$ They occur as both tailpieces and vignettes and as fullpage images, presented in the tradition of single plate engravings or etchings, which have, of course, to be printed separately from letter press. The use of 'full page' wood engravings in this small format suggests to me that the aim was to give some status to these fundamentally trivial if amusing images and, perhaps more speculatively, that the size of single page wood engraved image was what actually, literally, shaped the format of these annuals.

Other fads and fashions were even more short-lived. One publisher, William Kidd, briefly inaugurated and then ruthlessly exploited a momentary rage for the pamphlet publication of favourite comic poems combined with a set of full page, but still tiny, wood engraved images by the likes of Robert Cruikshank or Robert Seymour. Initially published in delicate paper covers, Kidd was shrewd enough to republish these works in a number of more permanent forms, the best known being the two volumes of Robert Cruikshank Facetiae. ${ }^{7}$ Again in these instances, the selling power of the highly finished comic wood engraved vignette was harnessed to well known and popular short comic texts to meet the new market hunger for illustrated amusement. The most interesting of these to me is the re-working of $\mathrm{W}$. T. Moncrieff's comic poem The March of Intellect, a work presumably derived from and made popular by stage versions of Pierce Egan's picaresque novel Life in London which had been extensively dramatised, most famously by Moncrieff himself. $^{8}$ While offering an essentially comic and factious view of a major social change, nonetheless the poem contains enough ambiguity about the new social order to be well worth further study, and Robert Cruikshank's illustrations are an excellent commentary. Equally short lived, but every bit as socially revealing, was the sudden appearance of caustic lithographed pastiche 'title pages' using grids of tiny images to satirise the new rage for periodicals, especially those of a self-improving nature.

C. J. Grant was the specialist at these but there a number of other artists involved,

Brian E. Maidment, Scraps and Sketches: Miscellaneity, Commodity Culture and Comic Prints, 1820-40

19: Interdisciplinary Studies in the Long Nineteenth Century, 5 (2007) www.19.bbk.ac.uk 
including Newman, the obscure but interesting artist who drew for The Squib (see fig. 8)..$^{9}$ In their simultaneous denunciation of the social and cultural pretensions of urban tradespeople and of the social habits of a new middle class uncertain how to exercise its new found social position, these images prefigure the kinds of social perspective offered by the early Punch cartoons.

It would be entirely possible to fill the rest of this paper with a full summary of the liveliness and commercial opportunism of the visual/verbal commodities offered to the new consumers of the 1820s and 1830s. Playtexts, for example, undergo crucial change during this period to accommodate the wood engraving, and to preserve some kind of commercial impetus in a theatrical culture deep in financial crisis. The Revel's History notes that 'almost the only plays printed [in this period] were in cheap acting editions designed for stage use and almost impossible to read for pleasure' - unless, it might be fair to say, you are a fan of wood engraving, or a scholar of Robert Cruikshank. ${ }^{10}$ Songbooks would provide another rich example - a totally under-utilised research resource ranging from the self-consciously genteel three volume Cruikshank illustrated Universal Songster to miniature Pocket Songsters and touching all points in between. Certainly such an astute and successful judge of the commercial scene as Edward Lloyd saw fit in the 1840s to develop a massive series of songbook titles which drew on his Regency predecessors, and developed the inter-relationship of wood engraving and song texts

see fig. 10). ${ }^{11}$ Alongside the democratisation of information and of the access to the technological process, during the 1820s wood engraving, and, less obviously but equally significantly, lithography were also democratising leisure reading, and providing a range of texts that evidently were not 'the novel' with a new format. It is in this context that I want to turn attention to the 'scrap' as a commercial form of visual culture and, eventually, to link it specifically to the mode of caricature.

II

Brian E. Maidment, Scraps and Sketches: Miscellaneity, Commodity Culture and Comic Prints, 1820-40

19: Interdisciplinary Studies in the Long Nineteenth Century, 5 (2007) www.19.bbk.ac.uk 
Narrowly defined 'scraps' were an aspect of commercial print making in the 1820s, 1830s and 1840s and comprised images deliberately produced, either in sheets or as small separate images, in the expectation that they would be cut out and reassembled as decorative pages in albums or scrap-books. In the first phases of the production of scraps, the images were sold in sheets and were used not just for albums, but also as decoration pasted on to household goods or even on to walls to act as friezes. Often they belonged to continuing series which were published on a weekly basis. Rickards, in his definitive work on printed ephemera, comments on such images that 'at this early period' scraps 'may be seen as a sub-section of the popular print industry' and it is important to acknowledge the commercial origins of scraps as well as the extent to which they drew genteel women into the print market. ${ }^{12}$ Initially, the 'use of these small prints as material for scrap books and albums was not envisaged, but they soon generated a renewed fad for the scrapbook/album'. ${ }^{13}$ However, by the middle of the nineteenth century scraps were being largely produced as cut out, brightly coloured lithographic images, deliberately aimed at the album market. These kinds of scraps drew extensively on German traditions of popular image making, where they were called 'Oblaten' or 'Glanzbilder' (literally 'wafers' or 'glossy pictures'). Thus, while the heyday of scraps was undoubtedly the late nineteenth century, when a vast range of brightly coloured lithographs were produced, the genre nonetheless has its origins in the more general expansion of the caricature and print trade between 1820 and 1840 . The extent of this market is easy enough to illustrate. By the early 1830s one publisher (Lacey) was advertising as part of his general stock '100 sheets of Scraps, beautifully drawn on stone, 6d. each [...] Plates from the Annuals [...] Comic sheets in great variety, 6d. each sheet [...] Twelve sheets of flowers, beautifully coloured [...] Fancy subjects, beautifully coloured [...] Fish, birds, butterflies, Insects, Game, Jars, Shells, etc.... '. ${ }^{14}$ An even more powerful argument for the importance of the trade opportunities offered by pre-printed material comes from the engraver-cumentrepreneur Henry Vizetelly. In his Glances Back Over Seventy Years Vizetelly, perhaps with a faint edge of jealousy, recalled the career of another print entrepreneur, Charles Tilt:

Brian E. Maidment, Scraps and Sketches: Miscellaneity, Commodity Culture and Comic Prints, 1820-40

19: Interdisciplinary Studies in the Long Nineteenth Century, 5 (2007) www.19.bbk.ac.uk 
[Tilt] had a genius for making money. He toiled and moiled at this one pursuit with the regularity of clockwork for a stated number of years, and retired from business at middle age with a considerable fortune. Not only were Tilt's publishing ventures successes, but when lithography was a novelty, and picture scrap books very general, and engravings with which to fill them rather rare, he imported from France large sheets crowded with designs, chiefly figure subjects by Victor Adam and others. For years Tilt had this trade almost entirely in his own hands, utilising the long side window of his shop to display the immense variety of his collection, and frequently turning over, I have heard him say, several hundred pounds per week, more than half of which was profit, from the sale of these lithographs alone. ${ }^{15}$

Evidence of this kind suggests the extensiveness of the trade, the variety of available images of all kinds in a broad range of reprographic media, and the considerable expense of such products. It also suggests the complex relationship between preprinted material and the structured spaces of the professionally produced elements of the scrapbook trade (for example, pages with raised or embossed decorative frames) and the variety of individual contributions made by compilers of albums, which combined such elements as calligraphic texts, watercolours, and decorative designs with pre-prepared elements drawn from trade productions.

The compilation of albums is usually understood as a 'pastime' enjoyed by 'middle class Victorian ladies' which exhibited the 'drawing room accomplishments' of 'well-to-do' women, many of them 'teenage girls from welleducated families'. ${ }^{16}$ Smith draws attention to two distinct phases of album making. The first spanned the first half of the nineteenth century and comprised a strong sense of textuality as well as an emphasis on the creative abilities and artistic accomplishments of the compiler. The second half of the century saw a more commercialised exploitation of album making as a hobby, drawing more and more on professionally produced images and increasingly incorporating greetings cards, trade cards or even pressed flowers. Clearly it is only the first phase that is relevant here.

Albums from this period often combined the pasting in of scraps or other printed ephemera with demonstrations of the artistic achievements of the compiler and her acquaintances through water colour painting, drawing or calligraphy. Often

\section{Brian E. Maidment, Scraps and Sketches: Miscellaneity, Commodity Culture and} Comic Prints, 1820-40

19: Interdisciplinary Studies in the Long Nineteenth Century, 5 (2007) www.19.bbk.ac.uk 
the compiler would extend or elaborate the material she had collected from elsewhere by hand, so that it sometimes hard to tell what is decoupage and what is hand painted. The albums themselves were extremely elaborately bound and frequently made to order with each customer seeking to outdo her friends through demanding elaborately tooled or embossed custom made bindings and watered silk end-papers. Each album tended to incorporate a florid lithographed title page (often hand coloured) which usually contained a considerable amount of self-referentiality either by depicting the making or communal reading of scrapbooks or through punning titles - Smith gives the example of 'scraps thankfully received'. Such a high degree of self-referentiality, especially in the form of a recognition of the sociable and communal aspects of making albums, runs throughout scrap culture, perhaps as a covert acknowledgement of the paradoxes and potential ironies of wealthy and leisured women spending their time accumulating and 'improving' something as trifling and ephemeral as the graphic 'scraps'.

But to my mind the most interesting aspect of early nineteenth-century album culture is the way in which albums serve to impose visual culture on the manners, social rituals and social interactions of their compilers and owners. Many albums are structured as keepsakes or 'traces' of friendships and social liaisons, and accordingly built as much out of the contributions of the friends and acquaintances of the owner as from the owner's personal creations or compilations. The rituals and protocols surrounding the use of albums as a focus of social interactions were complex, and they were fully, if sarcastically, explicated in an extended essay called 'The Adventures of an Album' in The Comic Offering for 1831. ${ }^{17}$ 'The Adventures of an Album' is an exercise in a familiar Victorian whimsical genre - the memoirs of a thing. The piece opens with a two line epigraph that hints at the emptiness of many a book - 'Tis pleasant sure to see oneself in print/ A book's a book though there's nothing in't' - a charge vehemently denied by the album which is full of 'charming poetry and unrivalled paintings'. The album continues with a detailed account of its own splendour - 'I am an exclusive' - and then extends on to an elaborately, though not bitingly, sardonic account of the competitiveness, jealousy and emptymindedness of the world that formed itself around album culture - a world of

Brian E. Maidment, Scraps and Sketches: Miscellaneity, Commodity Culture and Comic Prints, 1820-40

19: Interdisciplinary Studies in the Long Nineteenth Century, 5 (2007) www.19.bbk.ac.uk 
spurious accomplishment, hollow declarations of friendship, snobbery, and insincere flattery aimed at procuring the contribution of a published author or the attentions of eligible men. The memoir ends badly - the album is thrown, in a fit of its owner's bad temper, at a certain Mr. Danvers, and its lock is broken off. Worse follows. A contribution from Mr. Caustic is elicited and it comprises an anti-album diatribe of considerable force:

They will approach you with expression sweet,

And placing on your desk an album neat;

They'll flatter, praise, torment you and intreat

You'll labour for them:

(The sight of albums puts me in a heat,

I so abhor them).

The album concludes: 'In consequence of this spiteful, satirical, and unjust attack on all the fair herd of album keepers and contributors, no one will venture to add another page [...] so I am condemned to remain all the rest of my days, that pitiable and miserable object, a neglected, dusty, unfinished album!' ${ }^{18}$

It is informative that this long piece never mentions the possibility of albums containing scraps or, indeed, any other material drawn from contemporary commercial images. The emphasis is on the 'emptiness' of the contributions from which albums were assembled and on the sometimes absurd rituals and protocols which characterised album culture. Albums were, to their critics, books with no content. Yet the rituals of teasing out contributions, finding the most elaborate binding possible, and showing off the contents of an album, however trivial and competitive, do suggest the extent to which a new class of consumers - genteel young women - were being drawn in to the commercial networks of visual culture. Notions of gathering round and sharing graphic images, however competitively or vapidly motivated, have, by the 1830s, begun to extend beyond the camaraderie and connoisseurship of caricature which had almost exclusively belonged to men. The portfolios of caricatures and print which formed part of the staple business of the caricature and print trade in the late eighteenth century, and which could be borrowed overnight and viewed round the convivial male table accompanied by good food and ample wine, were giving way to the more domestic consumption of

Brian E. Maidment, Scraps and Sketches: Miscellaneity, Commodity Culture and Comic Prints, 1820-40

19: Interdisciplinary Studies in the Long Nineteenth Century, 5 (2007) www.19.bbk.ac.uk 
graphic images. If many of those images acknowledged such a shift from privileged genteel male scrutiny to a broader, more inclusive domestic audience in their content and form, nonetheless even albums from this period incorporated a miscellany of images which could situate a caricature by Robert Seymour or even a grotesque by C. J. Grant alongside topographical watercolours, decorative assemblages of fruits and carefully painted nosegays of flowers.

Yet despite all this evidence for use of scraps as part of the social rituals and protocols surrounding the genteel scrapbook, the group of artists and entrepreneurs who probably made most use of the scrap idea were the caricaturists, looking for ways of moving beyond the expensive single plate engraved or etched political satirical image without losing the irreverence and comic intensity of the caricature mode. Apart from Cruikshank's Scraps and Sketches, which has already been glimpsed, Cruikshank had already in 1821 produced something called Comic Composites for the Scrap Book. ${ }^{19}$ 'Composites' is a particularly interesting term to use here, mediating as it does between the culturally ambitious idea of 'compositions' and the rather less ambitious possibility of 'things lumped together'. Other caricaturists of the 1830s relentlessly exploited the possibilities of the comic scrap and its potential new market. An undated broadside sheet called Marks's New Universal Caricaturist published by J. L. Marks to advertise his stock describes his efforts to bring down the price of caricature so 'as to place Humorous and Whimsical sketches of men and manners within the reach of the humble and industrious classes of society, without making a heavy demand on the pocket'. Among the regular series of 'Graphic Illustrations, original and select' that Marks announced are two sheets of 'Comic Scraps' - a presence which suggests that even dedicated single sheet caricature publishers like Marks felt the need to acknowledge the scraps market. Even relatively upmarket print publishers like Ackermann recognised the need to include scraps in their lists, offering in the catalogue appended to W. H. Harrison’s The Humourist in 1832 ‘A new scrap title - intended

Brian E. Maidment, Scraps and Sketches: Miscellaneity, Commodity Culture and Comic Prints, 1820-40

19: Interdisciplinary Studies in the Long Nineteenth Century, 5 (2007) www.19.bbk.ac.uk 
to embellish either scrap books or album' and 'a large collection of drawings and prints for Scrap Books and Albums'. It is worth noting, however, that such products were hidden away right at the end of Ackermann's extensive catalogue after the many more glamorous and ambitious mezzotints after paintings, topographical and historical engravings, and even images of racehorses and railways. To some considerable extent such exploitation comprised a direct appeal to the scraps and album market, aligning caricature images with the picturesque lithographs of the scraps specialists and creating some of the jarring miscellaneousness that infected even the most genteel scrap albums. By 1825 the publisher William Tyas was producing a series of Humorous Scraps, with each plate crammed with miscellaneous small images. ${ }^{20}$ Some of these Humorous Scraps re-appear in a later compilation of Henry Heath's Tit Bits Selected by H. Heath. ${ }^{21}$ The enterprising McLean rapidly produced a rival series called, bluntly enough, McLean's Scraps for Albums, drawing on his stable of artists such as William Heath and Theodore Lane to provide the five or six images that made up each plate. ${ }^{22}$ These images were, unlike the Humorous Scraps, fully realised and quite substantial products that might easily have come from the sheets of any caricaturist of the time - what is happening here is that traditional caricature images are being marketed to the scraps market. Cruikshank's Scraps and Sketches (1828), as we have seen, follows this pattern, leaving McLean’s rival publisher, Tregear, to commission the remaining outstanding caricaturist Henry Heath for Tregear's Scraps, a series that came together with a self-referential title page like the altogether more ambitious Caricature Magazine (see fig. 10). . $^{3}$

But even without such specifically 'scrap' type projects, many caricaturists were everywhere re-thinking their work in terms of the new, extended market for visual culture made available by the scraps idea. Henry Heath, for example, no doubt enthused by his working relationship with Tregear, described his wide ranging compendium of previous work, organised into series of oblong folio plates comprising assemblages of smaller vignette images, as The Caricaturist's Scrap Book on its new title page, giving it a prefatory plate that offers an interesting image of how such material might be consumed by the whole household, including

Brian E. Maidment, Scraps and Sketches: Miscellaneity, Commodity Culture and Comic Prints, 1820-40

19: Interdisciplinary Studies in the Long Nineteenth Century, 5 (2007) www.19.bbk.ac.uk 
domestic servants (see fig. 11). That Heath was well aware of the transformation of his caricature sheets into scraps is made explicit in advertisements emanating from his then publisher, Charles Tilt, in 1834 where The Caricaturist's Scrap Book is described as 'several hundred humorous groups [...] in fifty seven sheets [...] will be found a never failing source of amusement for the fire-side circle and evening party'. ${ }^{24}$ Part of the 'never failing amusement', as the self-referential title page showing a family spending an evening looking at scrap sheets suggests, was in cutting out and reformulating Heath’s many images as scrapbooks and albums. But the most interesting configuration of all is when the feminised genteel scrap becomes not just contiguous to the caricature tradition of grotesque and satirical social commentary but also imperative in driving a new mode - the comic periodical built almost exclusively out of visual images. The first of these periodicals, for all its precarious and short-lived existence was the Glasgow Looking Glass, which almost immediately became The Northern Looking Glass. ${ }^{25}$ Together these two periodicals ran for seventeen issues between 1825 and 1826, with the caricaturist William Heath providing most of the graphic content. The format of the magazine evolved somewhat from a kind of samizdat broadsheet with the verbal elements reproduced by lithography in a simulacrum of handwriting, towards a perhaps more conventional combination of etching and typeset in later issues with the small illustrations being developed into little series, the best known of which offered waspish commentary on the shortcomings of the medical profession. While the page configuration of the Glasgow Looking Glass seems at first little more than another version of the caricaturist's 'omnium gatherum' it is the combination of the 'little' caricature vignette, perceived as a potential ‘scrap' as much as a fully realized satiric image and capable of being developed into a sequence of related images, with the new driving force of periodicity that drives forward the ageing and ailing caricature tradition into new forcefulness.

The Glasgow Looking Glass was soon followed by McClean's London based Looking Glass or Monthly Sheet of Caricatures, and then the various experiments of that most protean caricaturist, Charles Jameson Grant. ${ }^{26}$ In pursuit of the market, Grant's serial publications included a series of massive woodcuts mainly

Brian E. Maidment, Scraps and Sketches: Miscellaneity, Commodity Culture and Comic Prints, 1820-40

19: Interdisciplinary Studies in the Long Nineteenth Century, 5 (2007) www.19.bbk.ac.uk 
of political subjects and entirely subversive in their adaptation of a crudely drawn vernacular mode to sophisticated tastes; a run of satirical title pages mocking the self-improving tendencies of 'the march of intellect' and its serial publications, and produced as an assemblage of tiny lithographed images held within a ruled grid; and, most amenable of all to the scrap trade, Everybody's Album, which comprised large pages of small lithographed images, many within a grotesque idiom, and often using the punning visual jokes more familiar in wood engraved annuals at this time (see fig. 12).

As well as these developments which drew on metal engraving, etching and the new medium of lithography, comic wood engraving also found a proper form in Bell's Life in London, projected as a sporting journal but also keen to commission a range of humorous images, often organised as series with short accompanying texts. ${ }^{27}$ In the late 1820 s and 1830 s this periodical formed an excellent proving ground for new talent, especially comic artists keen to expand their public presence. The young John Leech, for example, drew a series of 'Paris originals', simply drawn sketches of French urban types each accompanied by a satirical poem as well as a series of pastiches of Sir Thomas Lawrence. Most germane here is another of Leech's contributions to Bell's Life in London, a 'Victoria Scrapbook for 1837', again comprising simple wood engravings accompanied by comic verses. The scale and simplicity of these images made them ideal material for the pages of scrapbooks, either with or without their accompanying verse (see fig. 13; fig. 17). Despite their origins in a weekly periodical, such images enjoyed a considerable afterlife, first as reprinted Galleries of Comicalities, a yearly gathering drawn from the comic graphic elements in Bell's Life which brought together series first published in different issues of the magazine on to a massive single folded sheet, sold for threepence, and suitable for both public display and the album maker's scissors. Part VI of the Gallery of Comicalities, published in 1837, boasted that 'one million five hundred thousand copies' of the previous five yearly issues had been sold. ${ }^{28}$ Even allowing for a publisher's characteristic exaggeration of his success, there is other evidence of the hold that the comic series in Bell's Life continued to have on the Victorian imagination. Late in the century, Charles Hindley republished

Brian E. Maidment, Scraps and Sketches: Miscellaneity, Commodity Culture and Comic Prints, 1820-40

19: Interdisciplinary Studies in the Long Nineteenth Century, 5 (2007) www.19.bbk.ac.uk 
many of the Gallery of Comicalities images in book form, using the same title and including work by Seymour and the Cruikshank brothers George and Robert. ${ }^{29}$

Alongside these weekly or monthly magazines and serials were the comic annuals already discussed, most successfully represented by Hood's Comic Annual, which remained popular for all of the 1830s, and which produced a host of imitators, especially the New Comic Annual with a mass of wood engravings by William Brown and the Comic Offering, which brought together a range of emerging illustrators including Robert Seymour (who drew the title page and frontispiece) and Kenny Meadows. Most successful of all was a serial that combined, largely through the medium of George Cruikshank's etchings and wood engraved vignettes, the popularity of the comic annual and the traditionally vernacular form of the almanac. The Comic Almanack was an extremely sophisticated amalgam of seriality, varying graphic modes and traditions (full page, if small scale, etchings as well as wood engraved vignettes), the comic energy of the new journalists soon to combine to form Punch, and a healthily sceptical view of contemporary culture, especially contemporary definitions of gentility, progress and urban developments. ${ }^{30}$

Though hardly the most sophisticated production, nonetheless Bell's Life in London looks startlingly refined when read against the kinds of short-lived small format weekly comic magazines published by the likes of W. Marshall. ${ }^{31}$ The fullpage wood engravings in these magazines were much closer to the crudest broadside images than to the refined reportage of the urban characters in Bell's Life. Such publications were little troubled by business ethics, often claiming that their illustrations were the product of artists like Robert Seymour or Robert Cruikshank despite obvious visual evidence to the contrary, eking out articles and illustrations by a high level of repetition, and shamelessly reprinting articles from other periodicals. Yet they do offer a rich, energetic and diverse visual account of street life in London, combining good humoured acceptance of diversity with a strong feel for the grotesque all brought together in wood engravings where crudity of outline is often combined with considerable linear flair. In a similar idiom, but much more sophisticated, is a largely ignored but extremely interesting and sustained serial comic version of London's streets, tradespeople and assorted ne'er-do-wells, Robert

Brian E. Maidment, Scraps and Sketches: Miscellaneity, Commodity Culture and Comic Prints, 1820-40

19: Interdisciplinary Studies in the Long Nineteenth Century, 5 (2007) www.19.bbk.ac.uk 
Seymour's New Readings of Old Authors (see fig. 14) . $^{32}$ Published by a wily entrepreneur, Charles Tilt, who was also the publisher of Heath's Caricature Scrap Book and the Comic Almanack, New Readings brought together a range of the latest ideas concerning the commercial potential of comic images. A small format monthly serial sustained over several years, each issue of New Readings comprised 11 or 12 lithographed comic images, each on a separate page, and each forming a visual pun on a quotation from 'old authors' - in fact, almost exclusively Shakespeare. The vogue for lithography was thus combined with the obsession for visual/verbal puns that had dominated published humour in the 1820s, and produced as a cumulative serial, with each part costing little enough, but the whole work making up a considerable expense.

It is the argument of this essay that these kinds of comic images - small in scale, serially produced, often crudely drawn, made rapidly either by lithography or wood engraving, and offering a view of urban life that still drew extensively on the grotesque and the carnivalesque city of the Regency imagination - formed the core of comic material that was redeployed into scrap books in the first half of the nineteenth century. Given the accidents of survival and destruction, the low critical regard that has attached itself to small scale comic image making during this period, and the often shocking visual disparity between the elegant and refined drawing room albums or scrapbooks devotedly and laboriously compiled by genteel young women, it is not always easy to find collections of scrap materials of the kind central to this argument. Thus any attempt to describe a 'characteristic' page of scraps from this period is at best tentative, although I have seen many examples of the kind reproduced here (see fig. 15; fig. 17; fig. 18; fig. 19; fig. 20; fig. 21; fig. 22). Many pages seem to have been built round a central image usually drawn from the single plate tradition, often engraved or etched, which might or might not be humorous. Round this central image are crowded an assemblage of smaller images, often lithographed or wood engraved, and most frequently derived from the kinds of sources outline above. In many pages, no distinction seems to be made between the visual and mental pleasures to be derived from various kinds of images. Comic or satirical images accompany topographical plates, portraits and genre scenes.

Brian E. Maidment, Scraps and Sketches: Miscellaneity, Commodity Culture and Comic Prints, 1820-40

19: Interdisciplinary Studies in the Long Nineteenth Century, 5 (2007) www.19.bbk.ac.uk 
Equally, metal engravings, etchings, lithographs and wood engravings, with all their tonal variation and varied implied audience, are jammed together within the margins of the page. As far as I have been able to tell the most popular sources of images were Bell's Life in London (both the tiny images from the title page (see fig. 13) and the urban 'characters', with or without their accompanying verses); Grant's small lithographs shows a page made up entirely from re-worked versions of Everybody's Album - almost as if the compiler wanted to edit his or her own periodical (see fig. 16 and also fig. 18); the New Comic Annual and its various imitators (see fig. 15; fig. 18); and images drawn from the various comic pamphlets produced by William Kidd in the early 1830s with tiny but refined wood engravings by the likes of Robert Cruikshank and Seymour see fig. 19).

IV

It goes almost without saying that the critical response to scraps, as representatives of the new market-driven, commodity visual culture of the 1820s and 1830s, has been generally dismissive. It is, however, worth spending a little time thinking through the intersections between aesthetic repulsion, snobbery, cultural theory and historical analysis that have led to such a unanimous narrative of the triviality, aesthetic failings, and even social irresponsibility that underlay the emergence of comic scraps into commercial viability and consumer delight.

The first narrative belongs particularly to two extremely influential commentators on early Victorian visual culture - Dorothy George and David Kunzle. Neither writer was centrally concerned with scraps. At the conclusion of her magnificent contribution to the study of caricature as a characteristically British socio-political phenomenon, the British Museum Catalogue of Political and Personal Satires, George, by training a social historian, was looking for explanations for the decline, indeed the demise, of a great satirical tradition of political caricature, manifested largely in the form of single plate engravings and etchings. ${ }^{33}$ Kunzle, in the course of another ambitious multi-volume project, a history of the comic strip in Europe and America, was pursuing an argument that

Brian E. Maidment, Scraps and Sketches: Miscellaneity, Commodity Culture and Comic Prints, 1820-40

19: Interdisciplinary Studies in the Long Nineteenth Century, 5 (2007) www.19.bbk.ac.uk 
saw the comic strip as a 'new' and widespread medium that emerged in the 1840s in response to the emptiness and triviality of the visual images commercially produced in the $1830 \mathrm{~s}^{34}$ Both analyses stressed that the $1820 \mathrm{~s}$ and 1830 s were a moment when one rich and genteel tradition of comic art faltered, became decadent, and was only slowly replaced by dynamic new media in the 1840s. Both commentators presented a narrative of decline and regeneration that linked aesthetic failure to the emergence of a massively extended consumer base. They both argued that the emergence of scraps as a significant visual genre was the inevitable and depressing consequence of attempts to broaden and/or democratise the market for caricature, and finally put an end to a complex and aesthetically successful caricature tradition in the 1830s. The aesthetic failure of caricature in the 1830s, emblematically represented by the triviality, inanity and cultural insignificance of the comedy 'scrap', can be directly related to the poor taste and lust for visual diversion of a new audience and market for visual culture cynically and thoughtlessly supplied by entrepreneurial and commercially opportunistic publishers and their artists. Dorothy George describes the 'disintegration' of the caricature tradition at this time: 'These five years [1828-1832] saw revolutionary changes in English caricature [...] the increasing use of lithography and wood engraving, the scrapbook, the illustrated newspaper'. The resulting images are described as 'crude, imitative, and repetitive (wood engravings in the radical press) or as 'degenerate' coloured etchings and lithographs. ${ }^{35}$ While she acknowledged that 'such things have an interest for the social historian' she maintains they have 'little to do with [...] comic art'. ${ }^{36}$ Yet George also noted that these 'degraded' images also carried 'into the new age the old symbols and traditions of caricature' ${ }^{37}$

Alongside this dismal picture of a vastly increased production of inferior and degraded images, George also saw the shift to a safer, more accommodated comic graphic tradition taking place. The mass production of satirical images, brought about by 'revolutionary' changes in the modes of production and discourses for caricature in the 1830s, resulted in a slackening of aesthetic achievement and a loss of precise, if satirical, political engagement. While comic image making began to move towards safer, less scatological, less personal bourgeois forms and genres this

Brian E. Maidment, Scraps and Sketches: Miscellaneity, Commodity Culture and Comic Prints, 1820-40

19: Interdisciplinary Studies in the Long Nineteenth Century, 5 (2007) www.19.bbk.ac.uk 
was at the expense of 'comic art'. David Kunzle formulated a similar narrative, describing the period as 'a satirical hiatus, the social impasse of a larger, less well educated audience that sought diversion rather than enlightenment, leaving the caricaturist free to say anything - or nothing at all' ${ }^{38}$ The result comprises 'inchoate miscellanies and whimsical ephemera ... frivolous, disjointed [...] flowing in no foreseeable direction [...] graphic bric a brac [...] of a metropolitan culture spewing and sprawling itself abroad, ${ }^{39}$ It is interesting to note how far Kunzle's sense of aesthetic outrage leads him to desert all historiographical sense - how would it be possible for a discourse as complex as scraps to say 'nothing at all'? Surely it would have something at least to say about the nature of its own discourse? This essay has certainly been written in the belief that such is the case - precisely what scraps have to say about their own discourse will form part of the concluding paragraphs.

A more persuasive, if still somewhat crude, way of explaining a scholarly disappointment at the admittedly 'trivial' content and often crudely drawn nature of commodity comedy prints of the 1820s and 1830s is offered by John Marriott's socio-political analysis of scraps as a form of repressed or diverted political energy. Marriot argues that the trivial graphic images that offered transient amusement and gratification were the product of the displacement of cultural energy away from the political arena (especially popular politics with its dependency on graphic codes and emblems) into boisterous and carnivalesque verbal and visual modes - exactly the transition that can be identified elsewhere in the shift from Figaro in London to the 'radical' early Punch and then the later, more whimsical, less politicised Punch. Acknowledging that the 'trajectories of graphic satire and popular drama after the phenomenal success of Life in London [Pierce Egan's 1821 novel] are difficult to trace and little understood', Marriott cites Louis James as describing 'a decline in the tradition of radical graphic satire after 1820, and the emergence mid-century of a trivial comic art of illustration'. ${ }^{40}$ But Marriott goes on from this orthodoxy to construct a rather different argument which re-defines 'triviality' in this context as the frustrated and displaced cultural expression of a failed and internalised political radicalism:

Brian E. Maidment, Scraps and Sketches: Miscellaneity, Commodity Culture and Comic Prints, 1820-40

19: Interdisciplinary Studies in the Long Nineteenth Century, 5 (2007) www.19.bbk.ac.uk 
Radicalism cohabited with the bawdy and the trivial inherited from a pre-industrial plebeian culture, and publishers ignored this at their cost [...] With the decline in radicalism, such publishers (as Fairburn) turned increasingly to other forms (joke books, pornography, songsters) so carrying forward into the Victorian era a populist, carnivalesque, antiestablishment culture which found expression in virtually all aspects of urban working class life. ${ }^{41}$

Marriott is clearly mounting here a polemical defence of the collective significance he finds in the bohemian/radical urban literature of the 1820s and 1830s as the source for much later writing about the city, a source which both predates and, he argues, pre-empts Dickens and Thackeray as the models for dominant Victorian modes of perceiving the city. Certainly his sense of the volatile, market driven formal and generic experimentation of the Regency and early Victorian period, is shared by another cultural historian, Richard Pound, whose work on satirical periodicals in this period is of considerable importance. Yet even Pound, who has seized on the cultural importance of the serialised production of mass circulation and politicised imagery in the 1830s as a major topic for scholarly investigation, concludes that 'the reduced scale and simplified graphic conventions of periodicalbased caricature (alongside a new reliance on supporting texts to explain images) had a reductive effect on graphic satire as an art form'. ${ }^{42}$ Both Marriott and Pound develop a properly historicized narrative to account for the aesthetic weaknesses of graphic comedy in the 1830s, but their model of mass circulation images as a means of incorporating a new mass audience into leisured and politically harmless leisure consumerism remains a somewhat crass one.

A more sophisticated formulation of similar ideas is to be found in arguments derived from cultural historians of the late Enlightenment period as it topples over into the Victorian period. In The Making of English Reading Audiences, 1790-1832, Jon Klancher regarded the shift to wide circulation and popular cultural commodities as often involving the kind of weakening of the Enlightenment ideas of knowledge, social participation and egalitarianism that he describes in his chapter on mass circulation journals like The Mirror of Literature, a relatively down-market journal that translated the traditional interests of the middle class miscellany into a newly industrialized world. For Klancher the creation of a mass audience 'displaces

Brian E. Maidment, Scraps and Sketches: Miscellaneity, Commodity Culture and Comic Prints, 1820-40

19: Interdisciplinary Studies in the Long Nineteenth Century, 5 (2007) www.19.bbk.ac.uk 
all discourses of political argument, philosophical speculation, and cultural discrimination one finds in Blackwood's Magazine or Edinburgh Review. Excluded from the dialogues of cultural power, the mass reader discovers an allegorical world overcrowded with signs'. ${ }^{43}$ Such a comment brings Klancher, albeit more intelligently, close to Kunzle's argument about a chaos of signification with almost nothing signified. Within this structure, Klancher goes on to read the 'contentless' mélange of information and images which characterized the Penny Magazine (1832) and the Saturday Magazine (1832) as politically and intellectually debilitating, offering their readers not so much a reflection of their own world as 'a longing, a utopian desire' which could never be fulfilled. ${ }^{44}$ Here we might see the failure of an Enlightenment project to construct a cross-class, educated 'reading community' of shared interests and with a common knowledge base. The potential application of this argument to the culture of scraps is obvious: scraps represent a fantasised urban world in which good humoured comic figures engage each other in a 'utopian desire' for carnivalesque good fellowship. In this 'allegorical world overcrowded with signs', urban realities are dissolved, by the processes of excision, reorganisation and re-presentation characteristic of making a scrap album, into manageable images that can be re-arranged on the page into pleasing and reassuring shapes and visual patterns. Scraps brought back to readers an egalitarianism and involvement in the world of signs and signification that had been largely lost in the world outside.

However far commercially produced prints of the 1820s and 1830s represent an aesthetic and cultural falling away from eighteenth-century practices, the argument of this essay has been that these two decades saw a massive increase in the commercial dynamism of the trade as it sought new modes of production, genres, and methods of consumption, especially within the domestic sphere. Scraps were central to these developments, and especially to the extension and democratisation of the market, for a range of reasons explored above - their appeal to women; their

Brian E. Maidment, Scraps and Sketches: Miscellaneity, Commodity Culture and Comic Prints, 1820-40

19: Interdisciplinary Studies in the Long Nineteenth Century, 5 (2007) www.19.bbk.ac.uk 
use of the bright colours of lithography; their cheapness; their ability to offer the consumer ways of restructuring and re-organising images into new meanings. But above all, scraps both represented and helped to drive seriality as a successful, even dominant, mode of publication in the first half of the nineteenth century. Scraps were also crucial in turning the inherent ephemerality of the serial, where another, newer, fresher issue turned up every week or month, into the permanency of the assembled album or scrapbook. In the declared or implicit function of the sheet of small comic images characteristic of graphic culture in the 1820s and 1830s as inviting the album maker's scissors, scraps enjoyed an ambiguous relationship for both consumer and publisher somewhere between ephemerality and permanence, between being treasured and being discarded, and thus between triviality and seriousness.

The importance of visual culture in the development of the early forms of seriality, especially exemplified in the lithographed caricature magazines of the 1820s and 1830s, the annuals and comic pamphlets of the early 1830s - all of which formed the staple material for many scrapbooks - challenges the heavy emphasis on the verbal aspects of print culture that has dominated historical accounts of seriality. To take one recent example of such an approach, Mark Bills, in the generally excellent and informative catalogue to an exhibition of visual satires of London life asserts, using a charming image of a print shop window as his main evidence that 'in the Regency period the print trade went full circle - the book trade predominated over the individual print seller and caricature, in effect, became a sideline of book and print sellers' ${ }^{45}$ I think this might well be true of the 1840 s, but not of the $1820 \mathrm{~s}$ and 1830s. In this period it seems to me, and I hope I have begun to assemble here some of the evidence that might be needed to substantiate this claim, it is the other way round. Visual culture, bursting with commercial and entrepreneurial energy and relentlessly in pursuit of the new possibility of the 'middle brow', drives the print trade more generally.

\section{List of Figures:}

Brian E. Maidment, Scraps and Sketches: Miscellaneity, Commodity Culture and Comic Prints, 1820-40

19: Interdisciplinary Studies in the Long Nineteenth Century, 5 (2007) www.19.bbk.ac.uk 
Fig. 1 George Cruikshank, Scraps and Sketches (1832), title page, etching.

Fig. 2 George Cruikshank, Scraps and Sketches (1832), Plate 22 'Tell Tale' (1 September 1832), etching.

Fig. 3 George Cruikshank, Scraps and Sketches (1832), Plate 2 'The Age of Intellect' (20 May 1828), etching.

Fig. 4 George Cruikshank, Scraps and Sketches (1832), Plate 10 'London Going Out of Town' (1 November 1829), etching.

Fig. 5 George Cruikshank, Scraps and Sketches (1832), Plate 5 'Ignorance is Bliss’ (10 May 1828), etching.

Fig. 6 The New Comic Annual (Charles Tilt, 1834), 64, wood engraving.

Fig. 7 Thomas Hood, The Comic Annual (Charles Tilt, 1834), 64, wood engraving.

Fig. 8 Anon., 'The Physiology of the Boyocracy', The Squib, 12 (13 August 1854), 50, wood engravings by William Newman.

Fig. 9 Lloyd's Songbook for 1849 (Edward Lloyd, 1949), title page to issue part 2, anonymous wood engraving.

Fig. 10 Title page from Tregear's Scraps (G. S. Tregear, 1830), lithograph.

Fig. 11 Henry Heath, The Caricaturist's Scrapbook, title page (Charles Tilt, 1840).

Fig. 12 C. J. Grant, Everybody’s Album (J. Kendrick, 15 June 1834), lithograph.

Fig. 13 Bell's Life in London - A Victoria Scrapbook for 1837 (William Clement, 1837), wood engravings by John Leech.

Fig. 14 Robert Seymour, New Readings of Old Authors - Pericles (Charles Tilt, n.d.), lithograph.

Brian E. Maidment, Scraps and Sketches: Miscellaneity, Commodity Culture and Comic Prints, 1820-40

19: Interdisciplinary Studies in the Long Nineteenth Century, 5 (2007) www.19.bbk.ac.uk 
Fig. 15 Scrapbook page comprising a central engraved image drawn from an unidentified series of Comic Scraps surrounded by wood engraved images from various sources including The New Comic Annual. Author's collection.

Fig. 16 Scrapbook leaf compiled entirely from images drawn from C. J. Grant's magazine Everybody’s Album, lithographs (detail). Author's collection.

Fig. 17 Scrapbook page made up of lithographs cut from Grant's magazines, wood engravings and text from Bell's Life in London, and engraved images from caricature plate. Author's collection.

Fig. 18 Scrapbook page centred around C. J. Grant's lithographed 'Frontispiece to the Singer’s Penny Magazine’ (G. Drake, 24 February 1835). Other images are drawn from Everybody's Album, The New Comic Annual and other unidentified sources. Author's collection.

Fig. 19 Scrapbook page with an engraved political caricature surrounded by various wood-engraved vignettes and engraved scraps. Author's collection.

Fig. 20 Scrapbook page with an engraved sentimental image surrounded by various wood-engraved scraps. Author's collection.

Fig. 21 Scrapbook page. Author’s collection.

Fig. 22 Scrapbook page. Authors’ collection.

\section{Endnotes:}

\footnotetext{
${ }^{1}$ George Cruikshank, Scraps and Sketches, 4 parts (London: G. Cruikshank, 1828-1832). See Albert N. Cohn, George Cruikshank: A Catalogue Raisonné (London: The Bookman’s Journal, 1924), pp. 57-58 for a full description. The work was re-issued in 1834, and again in 1854 as a ten part serial. There are other later Victorian issues, so the work suggests the way in which caricatures from the 1820s and 1830s remained commercially available for much of the Victorian period.

2 See, for example, F. G. Stephens and M. D. George, British Museum Catalogue of Political and Personal Satires, 11 vols (London: British Museum, 1870-1954), XI, xiii-xvii [hereafter BMC] and
}

\section{Brian E. Maidment, Scraps and Sketches: Miscellaneity, Commodity Culture and Comic Prints, 1820-40}

19: Interdisciplinary Studies in the Long Nineteenth Century, 5 (2007) www.19.bbk.ac.uk 
David Kunzle The History of the Comic Strip: The Nineteenth Century (Berkeley: University of California Press, 1990), pp. 20-21.

${ }^{3}$ There is a mass of information available for annuals, though the stress is very much on the literary content rather than the visual qualities of annuals. For listings see F. W. Faxon, Literary Annuals and Gift Books: A Bibliography (1823-1903) (London: Private Libraries Association, 1973). There are also excellent websites that offer a great deal of information. See Harry E. Hootman's web site on British Annuals and Giftbooks $<$ Hhttp://www.britannuals.comH $\mathrm{H}$ and the Science in the Nineteenth Century Periodical site $<$ Hhttp://www.sciper.orgH $>$ for much useful information.

${ }^{4}$ See Hootman and the Science in the Nineteenth Century websites.

${ }^{5}$ The Comic Offering; or Ladies' Melange of Literary Mirth ed. by Lady Louisa Sheridan (London: Smith, Elder \& Co. 1831-1835); W. H. Harrison, The Humourist, A Companion for the Christmas Fireside (London: R. Ackermann, 1832). The eighty wood engravings were by W. H. Brooke; R. Seymour, Seymour's Comic Album; or, Museum of Entertainment (London: W. Kidd, n.d.). Samuel Slader engraved Seymour's drawings; The New Comic Annual (London: Hurst, Chance \& Co., n.d.). The wood engravings were engraved by various people after drawings by William Brown.

${ }^{6}$ Comic Annual (London: Charles Tilt, 1834), p. 64.

${ }^{7}$ Facetiae; Being a General Collection of the Jeux D'Esprits which have been illustrated by Robert Cruikshank, 2 vols (London: William Kidd, 1830-31). The two volumes contained 13 illustrated works all of which had been previously separately issued by Kidd.

${ }^{8}$ W. T. Moncrieff, The March of Intellect (London: William Kidd, 1830).

${ }^{9}$ For Newman see R. K. Engen, Dictionary of Victorian Wood Engravers (Cambridge: ChadwyckHealey, 1985), pp. 192-3; M. H. Spielmann, The History of "Punch" (London: Cassell \& Company, 1895), pp. 413-414. Spielmann makes much of Newman’s production for Punch of small punning images in the manner of Hood.

${ }^{10}$ The Revels History of Drama in English, ed. by M. Booth et al, Vol. V: I 1750-1880 (London: Methuen, 1975), p. 52.

${ }^{11}$ Lloyd's seemingly endless productions of this kind, initially part issued but then reprinted in both volume form and as collections of volumes bound together, included Lloyd's Reciter, The Songs of Charles Dibdin, and Lloyd's Songbook in three series. None of these are dated.

${ }^{12}$ M. Rickards, The Encyclopaedia of Ephemera (London: The British Library, 2000), p. 284.

${ }^{13}$ Rickards, p. 284.

${ }^{14}$ Advertisement for Edward Lacey's publications on the end board of New Comic Annual (London: Hurst, Chance, n.d.).

${ }^{15}$ Henry Vizetelly, Glances Back Through Seventy Years, 2 vols (London: Kegan Paul, Trench, Trubner, 1893) I, p. 108.

\section{Brian E. Maidment, Scraps and Sketches: Miscellaneity, Commodity Culture and Comic Prints, 1820-40}

19: Interdisciplinary Studies in the Long Nineteenth Century, 5 (2007) www.19.bbk.ac.uk 
${ }^{16}$ Gaye Smith, Sentimental Souvenirs: Victorian Scrap Albums from the Sir Harry Page Collection (Manchester: Manchester Polytechnic Library, 1989), Introduction. The Sir Harry Page Collection is a major resource for the study of albums, and some glimpses of its contents can be found on the web site for Manchester Metropolitan University Library. See also Patrizia Di Bello Women's Albums and Photography in Victorian England: Ladies, Mothers and Flirts (Aldershot: Ashgate, 2007).

${ }^{17}$ The Comic Offering, ed. by Louisa Henrietta Sheridan, 251-285.

${ }^{18}$ Sheridan, The Comic Offering, 285.

${ }^{19}$ George Cruikshank, Comic Composites for the Scrap Book (London: S. W. Fores, 1821). See R. J. H. Douglas, The Works of George Cruikshank (London: J. Davy \& Sons, 1903), p. 178. First published by Fores in 1821, the Comic Composites were re-issued by W. B. Cooke in 1829.

${ }^{20}$ Henry Heath, Humorous Scraps (London: William Tyas, 1825). For images from this series see the digital collection of the Lewis Walpole Library at call number 825.10.12. All future references to this easily accessed resource will be abbreviated to LWL and the call number.

${ }^{21}$ Henry Heath, Tit-Bits Selected by H. Heath (London: J. Reynolds, 1830).

${ }^{22}$ LWL 826.0.37 to 826.0.41.

${ }^{23}$ LWL 830.0.095 to 098 and 830.0.101.

${ }^{24}$ Advertisement leaf at the end of Hood's Comic Annual for 1834 (London: Charles Tilt, 1834).

${ }^{25}$ The Glasgow Looking Glass ran fortnightly from June 11 1825, changing its name to The Northern Looking Glass after five issues. There is an excellent illustrated account of the magazine available at $<$ Hhttp://special.lib.gla.ac.uk/exhibns/month/june2005.htmlH $>$

${ }^{26}$ The Looking Glass ran from 1830 to 1836. Illustrators included both William and Henry Heath and Robert Seymour. Among the most significant and innovative of periodicals projected or illustrated by Grant were The Caricaturist (1831); Everybody's Album and Caricature Magazine (1834-5); The Penny Satirist (1837-46); and The Political Drama (1833-5). Richard Pound's 'Serial Journalism and the Transformation of English Graphic Satire 1830-36', unpublished Ph.D. thesis (University College London, 2002) provides an excellent account of satirical and comic periodicals in this period.

${ }^{27}$ Kunzle, pp. 21-22.

${ }^{28}$ The Gallery of Comicalities, Part VI (London: William Clement, n .d.).

${ }^{29}$ The Gallery of Comicalities Embracing Humorous Sketches by the Brothers Robert and George Cruikshank, Robert Seymour and Others (London: Charles Hindley, n. d.).

${ }^{30}$ The Comic Almanack ran in yearly issues from 1835 to 1853. As with many other regency and early Victorian comic publications, The Comic Almanack was reprinted in a popular two volume version by John Camden Hotten later in the century. As Vogler notes, Cruikshank's small etchings for this publication 'epitomise Cruikshank's transformation of the Regency caricature into the format of Victorian book illustrations': see Richard A. Vogler, Graphic Works of George Cruikshank (New York: Dover Publications, 1979), p. 152.

\section{Brian E. Maidment, Scraps and Sketches: Miscellaneity, Commodity Culture and Comic Prints, 1820-40}

19: Interdisciplinary Studies in the Long Nineteenth Century, 5 (2007) www.19.bbk.ac.uk 
31 The Comic Magazine boasted that it was 'illustrated with numerous comic engravings by $\mathrm{R}$. Cruikshank, \&c.' but on further inspection of the quality of the images, this seems extremely unlikely. The New Comic Magazine, Marshall’s successor to The Comic Magazine, proved to be hardly new due to frequent re-use of images previously published in the earlier journal.

${ }^{32}$ Robert Seymour, New Readings of Old Authors, 26 monthly parts (London: E. Wilson (issue 1), E. Wilson and Charles Tilt, then Charles Tilt, n. d.).

${ }^{33}$ BMC, XI, xiii-xvii.

${ }^{34}$ Kunzle, pp. 20-21.

${ }^{35}$ BMC, XI, xiii - xvii.

${ }^{36} B M C, \mathrm{XI}, \mathrm{xxi}$.

${ }^{37}$ BMC, XI, xvii.

${ }^{38}$ Kunzle, p. 20.

${ }^{39}$ Kunzle, p. 20.

40 J. Marriott, Unknown London: Early Modernist Visions of the Metropolis, 1815-45, 6 vols (London: Pickering \& Chatto, 2000), I, xxxix.

${ }^{41}$ Marriott, I, Xxxix.

42 Richard Pound, 'Serial Journalism and the Transformation of English Graphic Satire 1830-1836', Abstract.

43 Jon Klancher, The Making of English Reading Audiences, 1790-1832 (Madison: University of Wisconsin Press, 1987), p. 81.

${ }^{44}$ Klancher, p. 81.

${ }^{45}$ Mark Bills, The Art of Satire - London in Caricature (London: Philip Wilson, 2006), p. 140. 